\title{
PENGARUH KOMPETENSI, BUDAYA KERJA, DAN KEPUASAN KERJA TERHADAP KINERJA PEGAWAI DI BADAN KEPEGAWAIAN DAERAH KABUPATEN LABUHANBATU SELATAN
}

\author{
${ }^{1}$ Ali Brahamsar Nasution, ${ }^{2}$ Hasnah Harahap, ${ }^{3}$ Indra Arya, ${ }^{4}$ Sagiono, ${ }^{5}$ Agus Salim \\ $1,2,3,4,5$ Universitas Islam Sumatera Utara \\ lali.brahamsarnst@gmail.com, ${ }^{2}$ hasnah.harahap@gmail.com, ${ }^{3}$ indra.arya@gmail.com, ${ }^{4}$ sagiono.mm@gmail.com, \\ 5agus.salim@gmail.com
}

\begin{abstract}
Problem of this study how influence of competency on performance. How influence of job culture on performance. How influence of job satisfaction on performance. How influence competency, job culture and job satisfaction on performance. The purpose of this study to determine and analyze the effect of competency on performance. Determine and analyze the effect of job culture on performance. Determine and analyze the effect of job satisfaction on performance. Determine and analyze the effect of competency, job culture and job satisfaction on performance. Sample in the study is 34 employees. Data analysis techniques used in this study is descriptive analyze and multiple linear regression analysis. The results of the study indicate competency variable has a positive and significant effect on performance. Job culture variable has a positive and significant effect on performance. Job satisfaction variable has a positive and significant effect on performance. Competency, job culture and job satisfaction variable has a positive and significant effect on performance.
\end{abstract}

Keywords : Competency, Job culture, Job satisfaction, Performance.

ABSTRAK : Rumusan masalah dalam penelitian ini adalah apakah ada pengaruh kompetensi terhadap kinerja. Apakah ada pengaruh budaya kerja terhadap kinerja. Apakah ada pengaruh kepuasan kerja terhadap kinerja. Apakah ada pengaruh kompetensi, budaya kerja dan kepuasan kerja terhadap kinerja. Tujuan penelitian ini adalah untuk mengetahui dan menganalisis pengaruh kompetensi terhadap kinerja. Untuk mengetahui dan menganalisis pengaruh budaya kerja terhadap kinerja. Untuk mengetahui dan menganalisis pengaruh kepuasan kerja terhadap kinerja. Untuk mengetahui dan menganalisis pengaruh kompetensi, budaya kerja dan kepuasan kerja terhadap kinerja. Sampel dalam penelitian ini berjumlah 34 orang pegawai. Teknik analisis data yang digunakan dalam penelitian ini adalah analisis deskriptif dan analisis regresi linier berganda. Hasil penelitian ini menjelaskan bahwa variabel kompetensi berpengaruh positif dan signifikan terhadap kinerja. Variabel budaya kerja berpengaruh positif dan signifikan terhadap kinerja. Variabel kepuasan kerja berpengaruh positif dan signifikan terhadap kinerja. Variabel kompetensi, budaya kerja, dan kepuasan kerja berpengaruh positif dan signifikan terhadap kinerja

Kata kunci : Kompetensi, Budaya kerja, Kepuasan kerja, Kinerja

\section{Pendahuluan}

Salah satu fungsi pemerintah yang utama adalah menyelenggarakan pelayanan umum sebagai wujud dari tugas umum pemerintahan untuk mewujudkan kesejahteraan masyarakat. Birokrasi merupakan instrumen pemerintah untuk mewujudkan pelayanan publik yang efisien, efektif, berkeadilan, transparan dan akuntabel. Hal ini berarti bahwa untuk mampu melaksanakan fungsi pemerintah dengan baik maka organisasi birokrasi harus profesional, tanggap, aspiratif terhadap berbagai tuntutan masyarakat yang dilayani.

Seiring dengan hal tersebut pembinaan aparatur negara dilakukan secara terus menerus, agar dapat menjadi alat yang efisien, efektif, bersih dan berwibawa, sehingga mampu menjalankan tugas-tugas umum pemerintah maupun untuk menggerakkan pembangunan secara lancar dengan dilandasi semangat dan sikap pengabdian terhadap masyarakat. Oleh sebab itu pemerintah sebagai pelayan publik 
harus lebih mampu untuk memberikan pelayanan yang maksimal kepada rakyat. Sehingga kontribusi bagi perkembangan adalah terciptanya rasa kepercayaan kepada pemerintah akan meningkat. Tetapi apabila pelayanan tersebut tidak pernah didapatkan maka berbagai macam sifat buruk masyarakat terhadap pemerintah tidak dapat dibendung.

Dalam era pembangunan nasional peranan manusia selaku aparatur Negara semakin dirasakan kehadirannya. Seluruh keluaran organisasi organisasi tergantung dari prakarsa dan karya manusia, sehingga hampir setiap masalah pegawai sebagai aparatur dipandang sebagai Faktor yang menentukan keberhasilan program. Oleh karenanya Faktor manusia sebagai aparatur harus ditingkatkan semangat pengabdiannya, keterampilan dan kecakapannya, disiplin kerjanya yang keseluruhannya akan meningkatkan kewibawaan pemerintah.

Namun disisi lain, betapapun ahli dan keterampilan pegawai apabila pengelolaan tidak teratur dan sistematik maka pendayagunaanya tidak akan optimal, begitu pula sebaliknya bila pengelolaan teratur dan sistematik namun seorang pegawai tidak memiliki keahllian dan keterampilan pendayagunaan tidak akan optimal. Oleh sebab itu antara keahlian dan keterampilan pegawai dalam pengelolaan yang teratur dan sistematik untuk menghasilkan pendayagunaan yang optimal haruslah sejalan dan seimbang.

Kinerja dalam organisasi merupakan jawaban dari berhasil atau tidaknya tujuan organisasi yang telah ditetapkan. Para pemimpin atau manajer sering tidak

memperhatikan kecuali sudah amat buruk atau segala sesuatu jadi serba salah, Wirawan, (2017:66). Terlalu sering para pemimpin atau manajer tidak mengetahui betapa buruknya kinerja telah merosot sehingga organisasi/instansi menghadapi krisis yang serius. Kesan-kesan buruk organisasi yang mendalam berakibat dan mengakibatkan tandatanda adanya kinerja yang merosot.

Penelitian ini diarahkan untuk mengevaluasi dan menjelaskan fenomena kinerja birokrasi pemerintah di kantor Badan Kepegawaian Daerah Kabupaten Labuhanbatu Selatan. Variabel kinerja ini penting diteliti karena didasarkan atas alasan bahwa kinerja sebagai output yang diberikan kepada lingkungan akan sangat tergantung pada tinggi rendahnya kinerja proses. Hal ini berarti organisasi birokrasi pemerintah tak dapat meningkat kebertanggungjawabannya (accountability), kepercayaan menciptakan keadilan, efektivitas eksternal dan kepuasan masyarakat sebagai indikator kinerja eksternalnya tanpa memiliki kinerja internal yang baik.

Berdasarkan fenomena-fenomena diatas maka dapat dibandingkan dengan kinerja pegawai di Badan Kepegawaian Daerah Kabupaten Labuhanbatu Selatan yang hingga saat ini masih terdapat beberapa kekerungan seperti disiplin pegawai, sikap pegawai, penguasaan tugas-tugas pemerintah, dan hal lainnya. Sebagai gambaran umum dari kondisikondisi diatas dapat dilihat dari salah satu indikator pada data absensi pegawai kantor Badan Kepegawaian Daerah Kabupaten Labuhanbatu Selatan pada tahun 2020 sebagai berikut :

Tabel 1. Abensi Pegawai Badan Kepegawaian Daerah Kabupaten Labuhanbatu Selatan Tahun 2020

\begin{tabular}{|c|l|c|c|c|c|c|c|}
\hline \multirow{2}{*}{ No } & \multirow{2}{*}{ Bulan } & \multirow{2}{*}{ Jumlah } & \multirow{2}{*}{ Hari kerja } & \multicolumn{3}{|c|}{ Absensi } & Jumlah \\
\cline { 5 - 7 } & & & & Sakit & Izin & TK & Absensi \\
\hline 1 & Januari & 30 & 22 & 3 & 6 & 2 & 11 \\
\hline 2 & Februari & 29 & 21 & 2 & 5 & 3 & 10 \\
\hline 3 & Maret & 30 & 20 & 4 & 6 & 3 & 13 \\
\hline 4 & April & 30 & 22 & 3 & 7 & 4 & 14 \\
\hline 5 & Mei & 30 & 20 & 5 & 5 & 2 & 12 \\
\hline 6 & Juni & 30 & 23 & 4 & 5 & 3 & 12 \\
\hline 7 & Juli & 30 & 21 & 4 & 4 & 2 & 10 \\
\hline 8 & Agustus & 30 & 21 & 5 & 7 & 3 & 15 \\
\hline 9 & September & 30 & 22 & 3 & 8 & 4 & 15 \\
\hline 10 & Oktober & 30 & 22 & 4 & 5 & 3 & 1 \\
\hline
\end{tabular}




\begin{tabular}{|c|c|c|c|c|c|c|c|}
\hline \multirow{2}{*}{ No } & \multirow{2}{*}{ Bulan } & \multirow{2}{*}{ Jumlah } & \multirow{2}{*}{ Hari kerja } & \multicolumn{3}{|c|}{ Absensi } & Jumlah \\
\cline { 5 - 8 } & & & Sakit & Izin & TK & Absensi \\
\hline 11 & November & 30 & 22 & 4 & 4 & 2 & 10 \\
\hline 12 & Desember & 30 & 21 & 5 & 5 & 3 & 13 \\
\hline \multicolumn{2}{|l}{ Rata-rata } & 29,92 & 21,42 & 3,83 & 5,58 & 2,83 & 12,25 \\
\hline
\end{tabular}

Sumber : Badan Kepegawaian Daerah Kabupaten Labuhanbatu Selatan, 2021

Dari Tabel 1, diatas dapat diketahui bahwa masih ada pegawai yang absensinya belum optimal. Pada Tahun 2020 ditemukan rata-rata jumlah absensi pegawai sebesar 12,25. Salah satu indikator dari kinerja adalah kehadiran/keterlambatan pegawai, dikarenakan tingkat kehadiran pegawai pada Badan Kepegawaian Daerah Kabupaten Labuhanbatu Selatan masih dikategorikan belum optimal, dengan demikian dapat diambil kesimpulan bahwasannya pegawai dalam melaksakan tugas belum sepenuhnya terlaksana dengan baik, yang mana kehadiran merupakan salah satu hal yang berpengaruh dalam peningkatan kinerja dalam suatu instansi. Pada kondisi ini diasumsikan bahwa disiplin pegawai dan sikap pegawai dalam melaksanakan tugas dan program pemerintahan kurang maksimal, budaya kerja yang kurang baik dan kepuasan kerja yang kurang baik akan mengakibatkan semakin rendahnya tingkat kedisiplinan tersebut.

Dalam menunjang keberhasilan Badan Kepegawaian Daerah Kabupaten Labuhanbatu Selatan peranan pegawai merupakan aset yang sangat penting. Untuk dapat meningkatkan kinerja pegawai maka aspek kompetensi pegawai perlu ditingkatkan sehingga pegawai dapat bekerja sama dengan baik dalam tim. Wahyudi (2016:44), kompetensi adalah sebagai karakteristik-karateristik yang mendasari individu untuk mecapai kinerja superior. Kompetensi juga merupakan pengetahuan, ketrampilan, dan kemampuan yang berhubungan dengan pekerjaan, serta kemampuan yang dibutuhkan untuk pekejaan non rutin. Marliana (2011), dalam hasil penelitiannya menunjukkan adanya pengaruh yang positif dan signifikan dari kompetensi terhadap kinerja pegawai. Artinya kompetensi pegawai menstimulir optimasi pembentukan kinerja pegawai dalam bekerja di PT. Frisian Flag Indonesia Wilayah Sumatera Utara. Justisia Iriani Rudlia (2016), hasil penelitiannya menjelaskan kompetensi berpengaruh positif dan signifikan terhadap kinerja pegawai pada Dinas Kelautan dan Perikanan Kabupaten Kepulauan Sangihe. Sementara hasil penelitian terdahulu yang dilakukan oleh Anak Agung et al. (2012) menarik kesimpulan kompetensi berpengaruh negatif dan tidak signifikan terhadap kinerja pegawai di Kantor Dinas Pekerjaan Umum Provinsi Bali. Dari beberapa penelitian terdahulu tersebut menunjukkan adanya kesenjangan penelitian, sehingga hal ini menarik peneliti untuk melakukan penelitian lanjutan di Badan Kepegawaian Daerah Kabupaten Labuhanbatu Selatan.

Faktor lainnya yang dapat meningkatkan kinerja pegawai di Badan Kepegawaian Daerah Kabupaten Labuhanbatu Selatan adalah budaya kerja. Dimana budaya kerja merupakan cara pandang seseorang dalam memberi makna terhadap kerja. Dengan demikian, budaya kerja merupakan cara pandang seseorang terhadap bidang yang ditekuninya dan prinsip-prinsip moral yang dimiliki, yang menumbuhkan keyakinan yang kuat atas dasar nilai-nilai yang diyakini, memiliki semangat yang tinggi dan bersungguh-sungguh untuk mewujudkan prestasi terbaik, Robbins (2015:114). Budaya kerja adalah berpijak dari nilai-nilai yang dimiliki oleh bangsa atau masyarakat Indonesia yang diolah sedemikian rupa menjadi nilai-nilai baru yang akan menjadi sikap dan perilaku manajemen yang diharapkan dalam upaya menghadapi tantangan baru. Budaya kerja tidak akan muncul begitu saja, akan tetapi harus diupayakan dengan sungguh-sungguh melalui proses yang terkendali dengan melibatkan semua sumber daya manusia dalam seperangkat sistem, alat-alat dan teknik-teknik pendukung. Hasil penelitian terdahulu yang relevan dengan penelitian ini, diantaranya penelitian yang dilakukan oleh Hakim (2015), dan Alia et al. (2015), menunjukkan bahwa budaya kerja berpengaruh positif dan signifikan terhadap kinerja. Hasil penelitian yang relevan dilakukan oleh Artina et al. (2014), menyatakan dalam hasil penelitiannya bahwa budaya kerja berpengaruh negatif dan tidak signifikan terhadap kinerja. Berdasarkan riset gap tersebut, maka perlu diuji kembali secara empirik pengaruh budaya kerja terhadap kinerja 
pegawai di Badan Kepegawaian Daerah Kabupaten Labuhanbatu Selatan.

Faktor berikutnya yang mempengaruhi kinerja pegawai di Badan Kepegawaian Daerah Kabupaten Labuhanbatu Selatan adalah kepuasan kerja. Manusia pada dasarnya selalu berupaya untuk memenuhi kebutuhan hidupnya dengan berbagai cara, di antaranya dengan kerja. Seseorang akan memberikan sumbangan tenaga dan fikirannya secara optimal kepada organisasi tempat dia kerja, apabila seseorang dalam melaksanakan pekerjaannya merupakan salah satu yang perlu mendapat perhatian, karena hal tersebut akan meningkatkan kinerja oraganisasi secara keseluruhan. Hasibuan (2013:66), kepuasan kerja merupakan keadaan dalam diri seseorang yang merasa puas, lega dan senang karena situasi dan kondisi kerja yang dapat memenuhi segala yang berkaitan dengan kebutuhan, keinginan dan harapan. Teori keadilan berprinsip bahwa seseorang akan merasa puas atau tidak puas tergantung pada ada atau tidak adanya keadilan atas situasi tertentu. Perasaan ada atau tidak adanya keadilan diperoleh dengan cara membandingkan dirinya dengan orang lain yang setingkat. Bila perbandingan itu dianggap tidak adil maka orang yang bersangkutan akan merasa tidak puas terhadap pekerjaannya. Teori keadilan juga menunjukkan bahwa individuindividu tidak perduli dengan jumlah mutlak ganjaran yang mereka terima untuk upaya mereka, tetapi juga akan berhubungan jumlah ini dengan apa yang diterima orang lain. Mereka membuat pertimbangan seperti terhadap hubungan antara masukan dan keluaran mereka serta masukan dan keluaran orang lain. Masalah tentang kepuasan kerja pegawai Badan Kepegawaian Daerah Kabupaten Labuhanbatu Selatan antara lain masih ada pegawai merasa belum puas dengan promosi (promotion), rekan sekerja (co-wokers) dan atasan (supervisor). Hasil penelitian terdahulu yang relevan dengan penelitian ini, diantaranya penelitian yang dilakukan oleh anak Agung et al. (2012), Iwan Kurnia Wijaya (2018), Nyoman Dini Andiani (2020) dan Ali et al. (2013), telah menghasilkan kesimpulan yang relatif sama, yaitu bahwa kepuasan kerja mempunyai pengaruh yang positif dan signifikan terhadap kinerja. Hasil penelitian yang relevan dilakukan oleh Joko Sutopo (2018), menyatakan dalam hasil penelitiannya bahwa kepuasan kerja berpengaruh negatif dan tidak signifikan terhadap kinerja. Berdasarkan riset gap tersebut, maka perlu diuji kembali secara empirik pengaruh kepuasan kerja terhadap kinerja pegawai di Badan Kepegawaian Daerah Kabupaten Labuhanbatu Selatan.

Sebagai kesimpulan gambaran kinerja pegawai di Badan Kepegawaian Daerah Kabupaten Labuhanbatu Selatan secara umum dapat dilihat dari beberapa aspek dan salah satunya adalah dari tingkat kehadiran pegawai yang hanya dapat dikatakan cukup baik. Pada kondisi ini diasumsikan bahwa kinerja pegawai dalam melaksanakan program pemerintahan masih belum maksimal, budaya kerja yang kurang baik dan kepuasan kerja yang kurang baik pula akan mengakibatkan semakin rendahnya tingkat kinerja pegawai tersebut. Beberapa faktor yang mempengaruhi kinerja antara lain kompetensi, budaya kerja dan kepuasan kerja, dimana faktor ini sebelumnya telah diuji oleh beberapa peneliti terdahulu.

\subsection{Rumusan Masalah}

Berdasarkan indentifikasi dan batasan masalah tersebut diatas, maka penulis merumuskan masalah dalam penelitian ini yaitu

1) Apakah ada pengaruh kompetensi terhadap kinerja pegawai di Badan Kepegawaian Daerah Kabupaten Labuhanbatu Selatan.

2) Apakah ada pengaruh budaya kerja terhadap kinerja pegawai di Badan Kepegawaian Daerah Kabupaten Labuhanbatu Selatan.

3) Apakah ada pengaruh kepuasan kerja terhadap kinerja pegawai di Badan Kepegawaian Daerah Kabupaten Labuhanbatu Selatan.

4) Apakah ada pengaruh kompetensi, budaya kerja, kepuasan kerja terhadap kinerja pegawai di Badan Kepegawaian Daerah Kabupaten Labuhanbatu Selatan

\subsection{Batasan Masalah}

Karena kurangnya waktu, dan ilmu yang penulis miliki, maka dari masalah-masalah yang teridentifikasi tersebut penulis membatasi masalah yang akan diteliti hanya pada masalah kompetensi, budaya kerja, kepuasan kerja dan kinerja pegawai.

\subsection{Hipotesis}

Berdasarkan pada kerangka konseptual di atas, maka hipotesis dalam penelitian ini adalah : 
1) Ada pengaruh kompetensi terhadap kinerja pegawai di Badan Kepegawaian Daerah Kabupaten Labuhanbatu Selatan.

2) Ada pengaruh budaya kerja terhadap kinerja pegawai di Badan Kepegawaian Daerah Kabupaten Labuhanbatu Selatan.

3) Ada pengaruh kepuasan kerja terhadap kinerja pegawai di Badan Kepegawaian Daerah Kabupaten Labuhanbatu Selatan.

4) Ada pengaruh kompetensi, budaya kerja dan kepuasan kerja terhadap kinerja pegawai di Badan Kepegawaian Daerah Kabupaten Labuhanbatu Selatan.

\subsection{Tujuan Penelitian}

Tujuan dari penelitian ini adalah :

1) Untuk mengetahui dan menganalisis pengaruh kompetensi terhadap kinerja pegawai di Badan Kepegawaian Daerah Kabupaten Labuhanbatu Selatan.
2) Untuk mengetahui dan menganalisis pengaruh budaya kerja terhadap kinerja pegawai di Badan Kepegawaian Daerah Kabupaten Labuhanbatu Selatan.

3) Untuk mengetahui dan menganalisis pengaruh kepuasan kerja terhadap kinerja pegawai di Badan Kepegawaian Daerah Kabupaten Labuhanbatu Selatan.

4) Untuk mengetahui dan menganalisis pengaruh kompetensi, budaya kerja, kepuasan kerja terhadap kinerja pegawai di Badan Kepegawaian Daerah Kabupaten Labuhanbatu Selatan

\section{Metode Penelitian \\ 2.1. Populasi}

Populasi dalam penelitian ini adalah para pegawai Badan Kepegawaian Daerah Kabupaten Labuhanbatu Selatan yang berjumlah 34 orang. dimana Kepala Badan dan peneliti tidak dihitung sebagai populasi.

Tabel 2. Kerangka populasi pegawai

\begin{tabular}{|c|l|c|}
\hline No & \multicolumn{1}{|c|}{ Keterangan } & $\begin{array}{c}\text { Jumlah } \\
\text { (Orang) }\end{array}$ \\
\hline 1 & Sekretariat & 10 \\
\hline 2 & Bidang Program Pendataan Kepegawaian & 8 \\
\hline 3 & Bidang Mutasi & 9 \\
\hline 4 & Bidang Pengembangan dan Pemberdayaan Pegawai & 7 \\
\hline \multicolumn{2}{|c|}{ Jumlah } & 34 \\
\hline
\end{tabular}

Sumber : BKD Kabupaten Labusel, 2021

\subsection{Sampel}

Menurut Sugiyono (2011:93), sampel adalah elemen-elemen populasi yang dipilih atas dasar kemampuan mewakilinya. Untuk menjadi pedoman jika subjeknya atau populasinya kurang dari 100, maka lebih baik diambil semua sebagai sampel, sehingga penelitiannya merupakan penelitian populasi.
Selanjutnya jika jumlah subjeknya atau populasinya besar atau lebih dari 100, maka dapat diambil persentasenya. Dengan menggunakan teknik penarikan sampel yaitu total sampling atau metode sensus, maka sampel dalam penelitian ini berjumlah 34 orang pegawai di Badan Kepegawaian Daerah Kabupaten Labuhanbatu Selatan.

Tabel 3. Kerangka sampel pegawai

\begin{tabular}{|c|l|c|}
\hline No & \multicolumn{1}{|c|}{ Keterangan } & $\begin{array}{c}\text { Jumlah } \\
\text { (Orang) }\end{array}$ \\
\hline 1 & Sekretariat & 10 \\
\hline 2 & Bidang Program Pendataan Kepegawaian & 8 \\
\hline 3 & Bidang Mutasi & 9 \\
\hline 4 & Bidang Pengembangan dan Pemberdayaan Pegawai & 7 \\
\hline \multicolumn{2}{|c|}{ Jumlah } & 34 \\
\hline
\end{tabular}

\subsection{Uji Normalitas}

Model regresi yang baik adalah yang memiliki nilai residual yang terdistribusi normal. Untuk mengetahui bentuk distribusi data, bisa dilakukan dengan grafik distribusi dan analisis statistik. Pengujian dengan distribusi dilakukan dengan melihat grafik histogram yang membandingkan antara dua observasi dengan distribusi yang mendekati distribusi normal. Distribusi normal akan membentuk satu garis lurus diagonal dan ploating data residual akan dibandingkan 
dengan garis diagonal. Jika distribusi atau residual normal, maka garis yang menggambarkan data yang sesungguhnya akan mengikuti garis diagonalnya. Uji normalitas dengan grafik dapat dilakukan dengan program SPSS dengan analisis grafik Normal Probability Plot

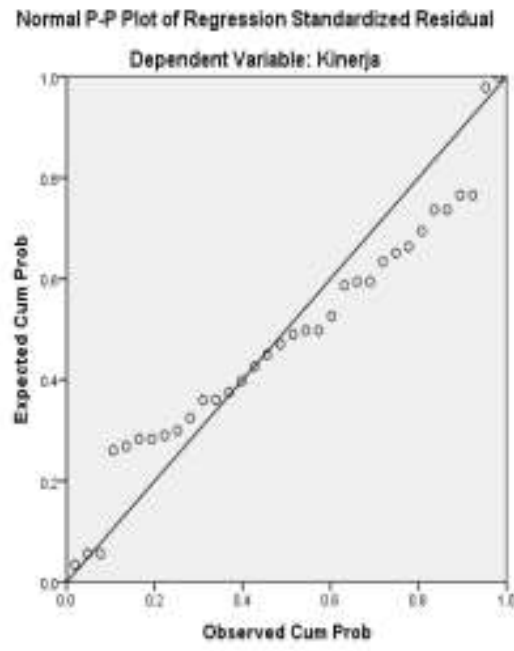

Gambar 1. Uji normalitas data

Berdasarkan gambar 1, diatas terlihat titiktitik dari ploating data residual berada di garis diagonal, hal ini dapat disimpulkan data yang diuji berdistribusi normal.

\subsection{Uji Multikolinieritas}

Salah satu asumsi dari model regresi linier bahwa tidak terjadi korelasi yang signifikan antara variabel bebasnya. Untuk menguji hal tersebut maka diperlukan suatu uji yang disebut uji multikolinieritas. Menurut Duwi Priyatno (2012:151) pengertian multikolinieritas adalah keadaan di mana pada model regresi ditemukan adanya korelasi yang sempurna atau mendekati sempurna antar variabel independen. Pada regresi yang baik seharusnya tidak terjadi korelasi yang sempurna atau mendekati sempurna diantara variabel bebas. Uji multikolinieritas adalah untuk melihat ada atau tidaknya korelasi yang tinggi antara variabelvariabel bebasnya, maka hubungan antara variabel bebas terhadap variabel terikatnya menjadi terganggu. Jika terdapat korelasi yang kuat dimana sesama variabel independen maka konsekuensinya adalah :

a. Koefisien-koefisien regresi menjadi tidak dapat ditaksir

b. Nilai standar error setiap koefisien regresi menjadi tidak terhingga.
Dengan demikian, semakin besar korelasi diantara sesama variabel independen maka tingkat kesalahan dari koefisien regresi semakin besar yang dapat mengakibatkan standar error semakin besar pula. Cara yang digunakan untuk mendeteksi ada tidaknya multikolinieritas adalah dengan melihat besarnya nilai Variance Inflation Factor (VIF). Jika VIF dibawah 10 dan Tolerance Value diatas 0,1 maka tidak terjadi multikolinieritas.

Tabel 4. Uji multikolinieritas

\begin{tabular}{l|c|c|}
\hline \multirow{2}{*}{ Variabel } & \multicolumn{2}{|c|}{ Collinearity Statistics } \\
\cline { 2 - 3 } & Tolerance & VIF \\
\hline Kompetensi & 0.896 & 1.116 \\
\hline Budaya kerja & 0.844 & 1.185 \\
\hline Kepuasan kerja & 0.835 & 1.197 \\
\hline $\begin{array}{l}\text { a. Dependent Variable : Kinerja } \\
\text { b. Hasil pengolahan data, 2021 }\end{array}$
\end{tabular}

Berdasarkan Tabel 4 diatas diperoleh nilai Tolerance Value diatas 0.1 yaitu $0.896,0.844$, dan 0.835 , hal ini menunjukan adanya korelasi yang cukup tinggi/kuat antara sesama variabel bebas dan nilai Variance Inflantion Factorrs (VIF) sebesar 1.116, 1.185, dan 1.197, dimana nilai VIF dari ketiga varibel bebas lebih kecil dari 10 dan dapat disimpulkan tidak terdapat multikolinieritas diantara ketiga variabel bebas yang diuji dalam penelitian ini.

\subsection{Uji Autokorelasi}

Uji autokorelasi merupakan pengujian dimana variabel dependen tidak berkorelasi dengan nilai variabel itu sendiri, baik nilai periode sebelumnya maupun nilai periode sesudahnya. Menurut Duwi Priyatno (2012:172) pengertian dari autokorelasi adalah keadaan di mana pada model regresi ada korelasi antara residual pada periode tertentu $t$ dengan residual pada periode sebelumnya ( $\mathrm{t}-1)$, model regresi yang baik adalah yang tidak terdapat masalah autokorelasi. Metode pengujian menggunakan uji Durbin-Watson (DW-test). Salah satu ukuran dalam menentukan ada tidaknya masalah autokorelasi dengan uji Durbin-Watson (DW) dengan ketentuan sebagai berikut :

- Terjadi autokorelasi positif jika nilai DW dibawah -2 atau DW $<-2$

- Tidak terjadi autokorelasi jika nilai DW diantara -2 dan +2 atau $-2<$ DW $<+2$

- Terjadi autokorelasi negatif jika nilai DW di atas 2 atau DW $>2$. 
Tabel 5. Uji Autokorelasi

\begin{tabular}{|l|c|c|c|c|c|c|}
\hline \multirow{4}{*}{ Model } & \multicolumn{5}{|c|}{ Change Statistics } & \multirow{2}{*}{$\begin{array}{c}\text { Durbin- } \\
\text { Watson }\end{array}$} \\
\cline { 2 - 6 } & $\begin{array}{c}\text { R Square } \\
\text { Change }\end{array}$ & F Change & df1 & df2 & $\begin{array}{c}\text { Sig. F } \\
\text { Change }\end{array}$ & \\
\hline 1 & .544 & 11.923 & 3 & 30 & .000 & 1.964 \\
\hline
\end{tabular}

Berdasarkan Tabel 5. di atas diperoleh nilai Durbin-Watson (DW) sebesar 1.964, nilai ini berada pada kisaran $-2<\mathrm{DW}<+2$, maka dapat disimpulkan bahwa tidak terjadi autokorelasi pada model regresi dalam penelitian ini.

\subsection{Uji Heteroskedastisitas}

Uji heteroskedastisitas bertujuan untuk menguji apakah dalam model regresi terjadi ketidaksamaan variance dari residual satu pengamatan ke pengamatan yang lainnya. Gejala variance yang tidak sama ini disebut dengan heteroskedastisitas, sedangkan adanya gejala residual yang sama dari satu pengamatan ke pengamatan lain disebut dengan homokedastisitas. Menurut Duwi Priyatno (2012:158) pengertian dari heteroskedastisitas adalah dimana dalam model regresi tejadi ketidaksamaan varian dari residual pada suatu pengamatan ke pengamatan yang lain. Model regresi yang baik adalah tidak terjadi heteroskedastisitas. Berbagai macam uji heteroskedastisitas yaitu dengan uji glejser, melihat pola titik-titik pada scatterplots regresi, atau uji koefisien korelasi spearman's.

Uji heteroskedastisitas dapat dilakukan dengan menggunakan grafik scatterplot antara nilai variabel terikat (ZSPRED) dengan residualnya (SRESID), dimana sumbu $X$ adalah yang diprediksi dan sumbu $\mathrm{Y}$ adalah residual. Dasar pengambilan keputusan yang dapat diambil adalah sebagai berikut :

a. Jika pola tertentu seperti titik-titik yang ada membentuk suatu pola yang teratur (bergelombang, melebar kemudian menyempit) maka telah terjadi heteroskedastisitas.

Tabel 6. Analisis regresi linier berganda

\begin{tabular}{|l|r|r|r|r|r|}
\hline \multirow{2}{*}{ Model } & \multicolumn{2}{|c|}{$\begin{array}{c}\text { Unstandardized } \\
\text { Coefficients }\end{array}$} & $\begin{array}{c}\text { Standardized } \\
\text { Coefficients } \\
\text { Beta }\end{array}$ & $\mathrm{t}$ & \multirow{2}{*}{ Sig. } \\
\cline { 2 - 3 } & \multicolumn{1}{c|}{$\mathrm{B}$} & Std. Error & & & \\
\hline (Constant) & 8.306 & 6.307 & & 1.317 & .198 \\
\hline Kompetensi & .551 & .130 & .552 & 4.236 & .000 \\
\hline Budaya kerja & .142 & .102 & .256 & 2.414 & .032 \\
\hline Kepuasan kerja & .234 & .096 & .329 & 2.435 & .021 \\
\hline
\end{tabular}

Hasil pengolahan data, 2021 b. Jika tidak ada yang jelas serta titik-titik menyebar diatas dan dibawah angka nol pada sumbu $\mathrm{Y}$ maka tidak terjadi heteroskedastisitas

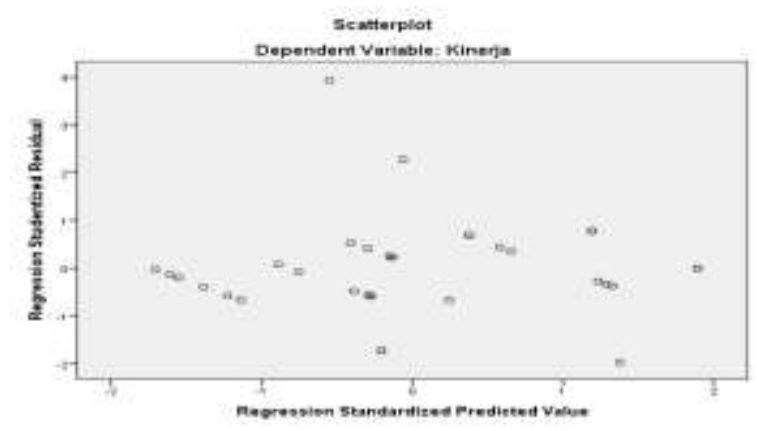

Gambar 2. Uji heteroskedastisitas

Berdasarkan gambar 2, diatas, menunjukkan titik-titik yang menyebar, sehingga dapat disimpulkan tidak terjadi heteroskedastisitas di data penelitian ini.

\section{Uji Hipotesis}

Dalam uji hipotesis ini peneliti akan melihat model persamaan regresi berganda dan akan menguji kebenaran hipotesis baik itu secara partial atau sendiri-sendiri, maupun secara simultan atau bersama-sama, dan untuk memudahkan peneliti dalam pengolahan data, maka digunakan Program Statistical Product and Service Solutions versi 22.00.

\subsection{Analisis Regresi Linier Berganda.}

Analisis regresi linier berganda dalam penelitian ini dapat dilihat dari persamaan regresinya, dan dari hasil pengolahan data diperoleh hasil berikut ini : 
Berdasarkan Tabel 6, diatas dapat dibuat persamaan regresi dalam penelitian ini sebagai berikut:

$$
\begin{gathered}
\mathrm{Y}=8.306+0.551 \mathrm{X}_{1}+0.142 \mathrm{X}_{2}+0.234 \mathrm{X}_{3} \\
+\mathrm{e}
\end{gathered}
$$

Dari persamaan regresi linier berganda di atas dapat dijelaskan :

1) Nilai kinerja pegawai di Badan Kepegawaian Daerah Kabupaten Labuhanbatu Selatan sebesar 8.306, yang mana nilai dari variabel dari variabel kompetensi, budaya kerja dan kepuasan kerja diabaikan.

2) Nilai koefisien regresi $X_{1}$ (kompetensi) mempunyai nilai positif yaitu 0.551 , hal ini menunjukkan bahwa variabel kompetensi mempunyai pengaruh yang searah dan positif terhadap kinerja pegawai di Badan Kepegawaian Daerah Kabupaten Labuhanbatu Selatan.

3) Nilai koefisien regresi $X_{2}$ (budaya kerja) mempunyai nilai positif yaitu 0.142 , hal ini menunjukkan bahwa variabel budaya kerja mempunyai pengaruh yang searah dan positif terhadap kinerja pegawai di Badan Kepegawaian Daerah Kabupaten Labuhanbatu Selatan.

4) Nilai koefisien regresi $X_{3}$ (kepuasan kerja) mempunyai nilai positif yaitu 0.234 , hal ini menunjukkan bahwa variabel kepuasan kerja mempunyai pengaruh yang searah dan positif terhadap kinerja pegawai di Badan Kepegawaian Daerah Kabupaten Labuhanbatu Selatan.

\subsection{Pengaruh Kompetensi Terhadap Kinerja Pegawai di Badan Kepegawaian Daerah Kabupaten Labuhanbatu Selatan.}

Untuk mengetahui pengaruh kompetensi terhadap kinerja pegawai di Badan Kepegawaian Daerah Kabupaten Labuhanbatu Selatan digunakan uji-t, sedangkan untuk melihat besarnya pengaruh digunakan nilai Beta atau Standardized Coefficient Beta.

Tabel. 7. Pengaruh kompetensi terhadap kinerja

\begin{tabular}{|l|r|r|r|r|r|}
\hline \multirow{2}{*}{ Model } & \multicolumn{2}{|c|}{$\begin{array}{c}\text { Unstandardized } \\
\text { Coefficients }\end{array}$} & \multirow{2}{*}{$\begin{array}{c}\text { Standardized } \\
\text { Coefficients } \\
\text { Beta }\end{array}$} & \multirow{2}{*}{$\mathrm{t}$} & \multirow{2}{*}{ Sig. } \\
\cline { 2 - 3 } & \multicolumn{1}{|c|}{$\mathrm{B}$} & \multicolumn{1}{|c|}{ Std. Error } & & \\
\hline (Constant $)$ & 8.306 & 6.307 & & 1.317 & .198 \\
\hline Kompetensi & .551 & .130 & .552 & 4.236 & .000 \\
\hline
\end{tabular}

a. Dependent Variable : Kinerja

Dari Tabel 7 diatas diperoleh nilai $t_{\text {hitung }}$ sebesar 4.236. Penelitian ini menggunakan taraf signifikansi ( $\alpha: 0.05)$ dan Derajat Kebebasan (DK) dengan ketentuan $\mathrm{DK}=\mathrm{n}-2$, atau $34-2$ $=32$. Dengan ketentuan tersebut, diperoleh nilai $t_{\text {tabel }}$ sebesar 2.036. Dengan kriteria hipotesis sebagai berikut :

Jika $t_{\text {hitung }}>t_{\text {tabel }}$, maka $\mathrm{H}_{0}$ ditolak dan $\mathrm{H}_{1}$ diterima.

Jika $\mathrm{t}_{\text {hitung }}<\mathrm{t}_{\text {tabel }}$, maka $\mathrm{H}_{0}$ diterima dan $\mathrm{H}_{1}$ ditolak.

Dari hasil pengolahan data diperoleh nilai $t_{\text {hitung }}>t_{\text {tabel }}(4.236>2.036)$ dan nilai signifikasi lebih kecil dari nilai $\alpha: 0.05$ yaitu $0.000<0.05$, sehingga $\mathrm{H}_{0}$ ditolak dan $\mathrm{H}_{1}$ diterima. Artinya variabel kompetensi secara partial berpengaruh positif dan signifikan terhadap kinerja pegawai di Badan Kepegawaian Daerah Kabupaten Labuhanbatu Selatan. Besarnya pengaruh variabel kompetensi terhadap kinerja pegawai di Badan Kepegawaian Daerah Kabupaten Labuhanbatu Selatan sebesar 0.552 atau $55.20 \%$.

\subsection{Pengaruh Budaya Kerja Terhadap Kinerja Pegawai di Badan Kepegawaian Daerah Kabupaten Labuhanbatu Selatan.}

Untuk mengetahui pengaruh budaya kerja terhadap kinerja pegawai di Badan Kepegawaian Daerah Kabupaten Labuhanbatu Selatan digunakan uji-t, sedangkan untuk melihat besarnya pengaruh digunakan nilai Beta atau Standardized Coefficient Beta.

Tabel 8. Pengaruh budaya kerja terhadap kinerja

\begin{tabular}{|l|r|r|r|r|r|}
\hline \multirow{2}{*}{ Model } & \multicolumn{2}{|c|}{$\begin{array}{c}\text { Unstandardized } \\
\text { Coefficients }\end{array}$} & $\begin{array}{c}\text { Standardized } \\
\text { Coefficients } \\
\text { Beta }\end{array}$ & \multirow{2}{*}{$\mathrm{t}$} & \multirow{2}{*}{ Sig. } \\
\cline { 2 - 3 } & \multicolumn{1}{|c|}{$\mathrm{B}$} & \multicolumn{1}{|c|}{ Std. Error } & & \\
\hline (Constant $)$ & 8.306 & 6.307 & & 1.317 & .198 \\
\hline Budaya kerja & .142 & .102 & .256 & 2.414 & .032 \\
\hline
\end{tabular}

a. Dependent Variable : Kinerja 
Dari Tabel 8 diatas diperoleh nilai $\mathrm{t}_{\text {hitung }}$ sebesar 2.414. Penelitian ini menggunakan taraf signifikansi $(\alpha: 0.05)$ dan Derajat Kebebasan (DK) dengan ketentuan DK $=\mathrm{n}-2$, atau $34-2$ $=32$. Dengan ketentuan tersebut, diperoleh nilai $t_{\text {tabel }}$ sebesar 2.036. Dengan kriteria hipotesis sebagai berikut :

Jika $t_{\text {hitung }}>t_{\text {tabel }}$, maka $\mathrm{H}_{0}$ ditolak dan $\mathrm{H}_{1}$ diterima.

Jika $\mathrm{t}_{\text {hitung }}<\mathrm{t}_{\text {tabel }}$, maka $\mathrm{H}_{0}$ diterima dan $\mathrm{H}_{1}$ ditolak.

Dari hasil pengolahan data diperoleh nilai $t_{\text {hitung }}>t_{\text {tabel }}(2.414>2.036)$ dan nilai signifikasi lebih kecil dari nilai $\alpha: 0.05$ yaitu $0.032<0.05$, sehingga $\mathrm{H}_{0}$ ditolak dan $\mathrm{H}_{1}$ diterima. Artinya variabel budaya kerja secara partial berpengaruh positif dan signifikan terhadap

kinerja pegawai di Badan Kepegawaian Daerah Kabupaten Labuhanbatu Selatan. Besarnya pengaruh variabel budaya kerja terhadap kinerja pegawai di Badan Kepegawaian Daerah Kabupaten Labuhanbatu Selatan sebesar 0.256 atau $25.60 \%$.

\subsection{Pengaruh Kepuasan Kerja Terhadap Kinerja Pegawai di Badan Kepegawaian Daerah Kabupaten Labuhanbatu Selatan.}

Untuk mengetahui pengaruh kepuasan kerja terhadap kinerja pegawai di Badan Kepegawaian Daerah Kabupaten Labuhanbatu Selatan digunakan uji-t, sedangkan untuk melihat besarnya pengaruh digunakan nilai Beta atau Standardized Coefficient Beta.

Tabel 9. Pengaruh kepuasan kerja terhadap kinerja

\begin{tabular}{|l|r|r|r|r|r|}
\hline \multirow{2}{*}{ Model } & \multicolumn{2}{|c|}{$\begin{array}{c}\text { Unstandardized } \\
\text { Coefficients }\end{array}$} & \multirow{2}{*}{$\begin{array}{c}\text { Standardized } \\
\text { Coefficients } \\
\text { Beta }\end{array}$} & \multirow{2}{*}{$\mathrm{t}$} & \multirow{2}{*}{ Sig. } \\
\cline { 2 - 3 } & \multicolumn{1}{|c|}{$\mathrm{B}$} & \multicolumn{1}{|c|}{ Std. Error } & & \\
\hline (Constant) & 8.306 & 6.307 & & 1.317 & .198 \\
\hline Kepuasan kerja & .234 & .096 & .329 & 2.435 & .021 \\
\hline
\end{tabular}

a. Dependent Variable : Kinerja

Dari Tabel 9, diatas diperoleh nilai $\mathrm{t}_{\text {hitung }}$ sebesar 2.435. Penelitian ini menggunakan taraf signifikansi $(\alpha: 0.05)$ dan Derajat Kebebasan (DK) dengan ketentuan DK $=\mathrm{n}-2$, atau $34-2$ $=32$. Dengan ketentuan tersebut, diperoleh nilai $t_{\text {tabel }}$ sebesar 2.036. Dengan kriteria hipotesis sebagai berikut :

Jika $t_{\text {hitung }}>t_{\text {tabel }}$, maka $\mathrm{H}_{0}$ ditolak dan $\mathrm{H}_{1}$ diterima.

Jika $\mathrm{t}_{\text {hitung }}<\mathrm{t}_{\text {tabel }}$, maka $\mathrm{H}_{0}$ diterima dan $\mathrm{H}_{1}$ ditolak.

Dari hasil pengolahan data diperoleh nilai $t_{\text {hitung }}>t_{\text {tabel }}(2.435>2.036)$ dan nilai signifikasi lebih kecil dari nilai $\alpha: 0.05$ yaitu $0.021<0.05$, sehingga $\mathrm{H}_{0}$ ditolak dan $\mathrm{H}_{1}$ diterima. Artinya variabel kepuasan kerja secara partial berpengaruh positif dan signifikan terhadap

Tabel 10. Pengaruh kompetensi, budaya kerja dan kepuasan kerja terhadap kinerja

\begin{tabular}{|l|l|r|r|r|r|c|}
\hline \multirow{3}{*}{ Model } & & $\begin{array}{c}\text { Sum of } \\
\text { Squares }\end{array}$ & \multicolumn{1}{c|}{$\mathrm{df}$} & $\begin{array}{c}\text { Mean } \\
\text { Square }\end{array}$ & \multicolumn{1}{c|}{ F } & Sig. \\
\hline \multirow{1}{*}{1} & Regression & 161.492 & 3 & 53.831 & 11.923 & $.000^{\mathrm{a}}$ \\
\cline { 2 - 8 } & Residual & 135.449 & 30 & 4.515 & & \\
\cline { 2 - 8 } & Total & 296.941 & 33 & & & \\
\hline
\end{tabular}

Dependent Variable : Kinerja

Hasil pengolahan data, 2021

Dari Tabel 10. di atas diperoleh nilai $\mathrm{F}_{\text {hitung }}$ sebesar 11.923. Penelitian ini menggunakan taraf signifikansi $(\alpha: 0.05)$ dan Derajat Kebebasan (DK) dengan ketentuan numerator : kinerja pegawai di Badan Kepegawaian Daerah Kabupaten Labuhanbatu Selatan. Besarnya pengaruh variabel kepuasan kerja terhadap kinerja pegawai Badan Kepegawaian Daerah Kabupaten Labuhanbatu Selatan sebesar 0.329 atau $32.90 \%$.

\subsection{Pengaruh Kompetensi, Budaya Kerja dan Kepuasan Kerja Terhadap Kinerja Pegawai di Badan Kepegawaian Daerah Kabupaten Labuhanbatu Selatan}

Untuk mengetahui pengaruh kompetensi, budaya kerja dan kepuasan kerja terhadap kinerja pegawai Badan Kepegawaian Daerah Kabupaten Labuhanbatu Selatan digunakan ujiF. 
3.330. Dengan kriteria pengujian hipotesis sebagai berikut :

Jika $\mathrm{F}_{\text {hitung }}>\mathrm{F}_{\text {tabel }}$, maka $\mathrm{H}_{0}$ ditolak dan $\mathrm{H}_{1}$ diterima.

Jika $\mathrm{F}_{\text {hitung }}<\mathrm{F}_{\text {tabel }}$, maka $\mathrm{H}_{0}$ diterima dan $\mathrm{H}_{1}$ ditolak.

Dari hasil perhitungan diperoleh nilai $\mathrm{F}_{\text {hitung }}$ $>\mathrm{F}_{\text {tabel }}(11.923>3.330)$ dan nilai signifikasi $0.000<0.05$, sehingga $\mathrm{H}_{0}$ ditolak dan $\mathrm{H}_{1}$ diterima. Artinya variabel kompetensi, budaya kerja dan kepuasan kerja secara simultan berpengaruh positif dan signifikan terhadap kinerja pegawai di Badan Kepegawaian Daerah Kabupaten Labuhanbatu Selatan. Dengan demikian model regresi ini sudah layak dan

Tabel 11. Model summary ${ }^{\mathrm{b}}$ pengaruh kompetensi, budaya kerja dan kepuasan kerja terhadap kinerja

\begin{tabular}{|c|c|c|c|c|}
\hline Model & $\mathrm{R}$ & $R$ Square & $\begin{array}{l}\text { Adjusted } R \\
\text { Square }\end{array}$ & Std. Error of the Estimate \\
\hline 1 & $.737^{\mathrm{a}}$ & .544 & .498 & 2.12484 \\
\hline
\end{tabular}

Dependent Variable : Kinerja

Hasil pengolahan data, 2021

Besarnya Tabel 11 diatas diperoleh nilai Rsquare $\left(\mathrm{r}^{2}\right)$ sebesar 0.544. Nilai tersebut mempunyai maksud bahwa pengaruh kompetensi, budaya kerja dan kepuasan kerja terhadap kinerja pegawai di Badan Kepegawaian Daerah Kabupaten Labuhanbatu Selatan sebesar $54.40 \%$, sedangkan sisanya sebesar $45.60 \%$ dipengaruhi oleh faktor-faktor lain yang tidak diteliti. Dengan kata lain variabel kinerja pegawai di Badan Kepegawaian Daerah Kabupaten Labuhanbatu Selatan dapat diterangkan oleh variabel kompetensi, budaya kerja dan kepuasan kerja sebesar $54.40 \%$, sedangkan sisanya sebesar $45.60 \%$ disebabkan oleh variabel-variabel lain yang tidak diteliti seperti gaji, fasilitas kerja, kepemimpinan dan lain sebagainya.

\section{Evaluasi Data}

4.1. Pengaruh Kompetensi Terhadap Kinerja Pegawai di Badan Kepegawaian Daerah Kabupaten Labuhanbatu Selatan.

Berdasarkan pada hasil penelitian dapat dijelaskan bahwa kompetensi berpengaruh positif dan signifikan terhadap kinerja pegawai di Badan Kepegawaian Daerah Kabupaten Labuhanbatu Selatan. Hasil penelitian ini sejalan dengan hasil penelitian terdahulu dari Marliana (2011), dan Justisia Iriani Rudlia (2016), keduanya menyatakan bahwa kompetensi berpengaruh positif dan signifikan benar dan dapat disimpulkan bahwa variabel kompetensi, budaya kerja dan kepuasan kerja berpengaruh terhadap kinerja pegawai di Badan Kepegawaian Daerah Kabupaten Labuhanbatu Selatan.

\subsection{Uji Determinan}

Uji determinan adalah untuk mengetahui seberapa besar pengaruh variabel kompetensi, budaya kerja dan kepuasan kerja terhadap kinerja pegawai Badan Kepegawaian Daerah Kabupaten Labuhanbatu Selatan, dan dapat dilihat dari model summary, khususnya nilai Rsquare.

terhadap kinerja. Akan tetapi hasil penelitian bertentangan dengan hasil penelitian terdahulu dari Anak Agung et al. (2012), yang membuat kesimpulan bahwa kompetensi berpengaruh negatif dan tidak signifikan terhadap kinerja. Dari hasil penelitian ini dapat dijelaskan bahwa kompetensi pegawai di Badan Kepegawaian Daerah Kabupaten Labuhanbatu Selatan secara keseluruhan pada saat ini dalam kategori baik dan dapat meningkatkan kinerja pegawai.

\subsection{Pengaruh Budaya Kerja Terhadap Kinerja Pegawai di Badan Kepegawaian Daerah Kabupaten Labuhanbatu Selatan.}

Berdasarkan pada hasil penelitian dapat dijelaskan bahwa budaya kerja berpengaruh positif dan signifikan terhadap kinerja pegawai di Badan Kepegawaian Daerah Kabupaten Labuhanbatu Selatan. Hasil penelitian ini sejalan dengan hasil penelitian terdahulu dari Hakim (2015), dan Alia et al. (2015), kesemuanya menyatakan bahwa budaya kerja berpengaruh positif dan signifikan terhadap kinerja. Akan tetapi hasil penelitian bertentangan dengan hasil penelitian terdahulu dari Artina et al. (2014), yang membuat kesimpulan bahwa budaya kerja berpengaruh negatif dan tidak signifikan terhadap kinerja. Dari hasil penelitian ini dapat dijelaskan bahwa budaya kerja yang tercipta di Badan Kepegawaian Daerah Kabupaten Labuhanbatu 
Selatan secara keseluruhan pada saat ini dalam kategori baik dan dapat meningkatkan kinerja pegawai.

\subsection{Pengaruh Kepuasan Kerja Terhadap Kinerja Pegawai di Badan Kepegawaian Daerah Kabupaten Labuhanbatu Selatan.}

Berdasarkan pada hasil penelitian dapat dijelaskan bahwa kepuasan kerja berpengaruh positif dan signifikan terhadap kinerja pegawai di Badan Kepegawaian Daerah Kabupaten Labuhanbatu Selatan. Hasil penelitian ini sejalan dengan hasil penelitian terdahulu dari Agung et al. (2012), Iwan Kurnia Wijaya (2018), Nyoman Dini Andiani (2020) dan Ali et al. (2013), kesemuanya menyatakan bahwa kepuasan kerja berpengaruh positif dan signifikan terhadap kinerja. Akan tetapi hasil penelitian bertentangan dengan hasil penelitian terdahulu dari Joko Sutopo (2018), yang membuat kesimpulan bahwa kepuasan kerja berpengaruh negatif dan tidak signifikan terhadap kinerja. Dari hasil penelitian ini dapat dijelaskan bahwa kepuasan kerja pegawai di Badan Kepegawaian Daerah Kabupaten Labuhanbatu Selatan secara keseluruhan pada saat ini dalam kategori baik dan dapat meningkatkan kinerja pegawai.

\subsection{Pengaruh Kompetensi, Budaya Kerja dan Kepuasan Kerja Terhadap Kinerja Pegawai di Badan Kepegawaian Daerah Kabupaten Labuhanbatu Selatan.}

Berdasarkan pada hasil penelitian dapat dijelaskan bahwa kompetensi, budaya kerja dan kepuasan kerja berpengaruh positif dan signifikan terhadap kinerja pegawai di Badan Kepegawaian Daerah Kabupaten Labuhanbatu Selatan. Dari hasil penelitian ini dapat dijelaskan bahwa kompetensi, budaya kerja dan kepuasan kerja pegawai di Badan Kepegawaian Daerah Kabupaten Labuhanbatu Selatan secara keseluruhan pada saat ini dalam kategori baik dan dapat meningkatkan kinerja pegawai secara bersama-sama.

\section{Kesimpulan}

Berdasarkan uraian diatas, maka dapat diambil kesimpulan sebagai berikut :

1) Kompetensi berpengaruh positif dan signifikan terhadap kinerja pegawai Badan Kepegawaian Daerah Kabupaten Labuhanbatu Selatan.
2) Budaya kerja berpengaruh positif dan signifikan terhadap kinerja pegawai Badan Kepegawaian Daerah Kabupaten Labuhanbatu Selatan.

3) Kepuasan kerja berpengaruh positif dan signifikan terhadap kinerja pegawai Badan Kepegawaian Daerah Kabupaten Labuhanbatu Selatan.

4) Kompetensi, budaya kerja dan kepuasan kerja berpengaruh positif dan signifikan terhadap kinerja pegawai Badan Kepegawaian Daerah Kabupaten Labuhanbatu Selatan.

\section{DAFTAR PUSTAKA}

Dessler, Garry (2015), Manajemen Sumber Daya Manusia, PT. Preshelindo, Jakarta

Handoko T, Hani (2013), Manajemen Personalia dan Sumber Daya Manusia, Edisi Kedua, BPFE Yogyakarta.

Hasibuan, Malayu, SP (2013), Manajemen Sumber Daya Manusia, PT. Bumi Akasara Jakarta.

Mangkunegara AP, (2015), Perencanaan dan Pengembangan Sumber Daya Manusia, Rfika Aditama, Bandung

Mangkuprawira, Sjafri, (2009), Manajemen Sumber Daya Manusia. Strategik, Ghalia Indonesia,Jakarta

Mathis L. Robert dan Jackson H. John alih bahasa oleh Sadeli (2012), Manajemen Sumber Daya Manusia, Salemba Empat Jakarta.

Nawawi H (2013), Manajemen Sumber Daya Manusia, PT. Rineka Cipta, Jakarta.

Prawirosentono, Suryadi (2010), Kebijakan Kinerja Pegawai, BPFE Yogyakarta.

Robbins Stephen, (2015), Perilaku Organisasi, Penerbit Salemba Empat, Jakarta

Robbins, P.Stephen dan Timothy A. Judge (2012), Perilaku Organisasi. Salemba Empat. Jakarta

Samsudin, Sadili. (2009). Manajemen Sumber Daya Manusia. Bandung, CV. Pustaka Setia

Sedarmayanti (2017), Perencanaan dan Pengembangan Sumber Daya Manusia, PT Refika Aditama, Bandung

Siagian P. Sondang (2013), Teori dan Praktek Pengambilan Keputusan, Cetakan kedua, CV. Haji Masagung Jakarta

Sugiyono (2014), Metode Penelitian Bisnis, Alfabeta, Bandung

Wahjosumidjo (2015), Kepemimpinan dan Motivasi, Liberty Yogyakarta 
Wahyudi (2016). Manajemen Sumber Daya Manusia. UMM Press, Malang

Wirawan, (2017). Manajemen Perilaku Organisasi, Edisi Revisi Cetakan Pertama, Prenada Media, Jakarta

\section{Jurnal :}

Alia, Cut Fauza, Mukhlis Yunus dan Mahdani (2015), "Pengaruh Budaya Perusahaan, Rotasi Dan Promosi Jabatan Terhadap Motivasi Serta Implikasinya Pada Kinerja Karyawan PT. Bank Mandiri (Persero) Tbk. Area Banda Aceh." Jurnal Manajemen Pascasarjana Universitas Syiah Kuala. ISSN: 2302- 0199. Vol. 4, No. 1, Hal. 1-10.

Ali, M., Idris, A., \& Kalalinggi, R., (2013). Pengaruh kepuasan kerja terhadap kinerja pegawai pada Badan Ketahanan Pangan Dan Pelaksana Penyuluhan Daerah Kota Samarinda. eJournal Administrative Reform, 2013, 1(2), 418-430

Anak Agung Ngurah Bagus Dhermawan, I Gde Adnyana Sudibya, I Wayan Mudiartha Utama (2012), Pengaruh Motivasi, Lingkungan Kerja, Kompetensi, Dan Kompensasi Terhadap Kepuasan Kerja Dan Kinerja Pegawai Di Lingkungan Kantor Dinas Pekerjaan Umum Provinsi Bali, Jurnal Manajemen, Strategi Bisnis, dan Kewirausahaan Vol. 6, No. 2 Agustus 2012.

Artina, H.B. Isyandi, dan Sri Indarti. (2014). "Pengaruh Kepemimpinan, Budaya Kerja, Lingkungan Kerja Terhadap Disiplin Kerja dan Kinerja Personil Polda Riau." Jurnal Tepak Manajemen Bisnis. Vol. VI, No. 2, Hal. 9-19

Fajar Syahputra (2013) Pengaruh Kompetensi, Budaya Kerja Dan Kepuasan Kerja Terhadap Kinerja Pegawai Pada Kantor Camat Meral Kabupaten Karimun. Skripsi thesis, Universitas Islam Negeri Sultan Syarif Kasim Riau, http://repository.uinsuska.ac.id/9217/

Kartini (2015), Pengaruh Kompetensi, Komitmen Organisasi Serta Budaya Organisasi Terhadap Kepuasan Kerja Dan Kinerja Pegawai Pada Sekretariat Daerah Kabupaten Kutai Timur, Jurnal Paradigma, Vol. 4 No. $1, \quad$ http://ejournals.unmul.ac.id/index.php/JParadigma /article/view/405

Iwan Kurnia Wijaya (2018), Pengaruh Kepuasan Kerja Terhadap Kinerja
Karyawan CV Bukit Sanomas, AGORA Vol. 6, No. 2 (2018)

Joko Sutopo (2018), Pengaruh Partisipasi Anggaran, Komitmen Organisasi, Kepuasan Kerja, Job Relevant Information, Budaya Organisasi Dan Locus Of Control Terhadap Kinerja Pegawai Bagian Keuangan Dinas Pendidikan Kabupaten Klaten, ADVANCE VOL.5 No.1 Edisi Maret 2018. Kepuasan ke kin negatif

Justisia Iriani Rudlia (2016), Pengaruh Kompetensi dan Kompensasi terhadap Kepuasan Kerja dan Kinerja Pegawai (Studi Kasus Pada Dinas Kelautan dan Perikanan Kabupaten Kepulauan Sangihe, Jurnal Riset Bisnis dan Manajemen Vol 4 ,No.3, 2016: 257-268

Marliana Budhiningtias Winanti (2011), Pengaruh Kompetensi terhadap kinerja karyawan Survei pada Frisian Flag Indonesia Wilayah Sumatra Utara

Nyoman Dini Andiani (2020), Pengaruh Stres Kerja Dan Kepuasan Kerja Terhadap Kinerja Karyawan PT. BPR Sedana Murni, Prospek: Jurnal Manajemen dan Bisnis, Vol 2 No. 1, Juli 2020, P-ISSN: 26855526.

Sri Handoko Budi Nugroho, Achmad Choerudin, Winarna (2012), Pengaruh Budaya Kerja dan Lingkungan Kerja terhadap Kinerja melalui Motivasi dan Komitmen Organisasi (Studi di Komisi Pemilihan Umum Kabupaten Karanganyar), Downloads/165-321-1SM.pdf. 